Flere henvisninger til nyrelege

Nyrefunksjonen kan være betydelig redusert før det avspeiles i forhøyet plasmakreatininmåling. Estimert glomerulær filtrasjonsrate (eGFR) er et beregnet estimat ut fra plasmakreatinin, alder og kjønn, og kan være bedre til vurdering av nyrefunksjon (JAMA 2010; 303: 1151-8).

I en ny kanadisk studie undersøkte forfatterne endringer $\mathrm{i}$ henvisningsmønsteret til nefrolog hos 1,1 millioner voksne før og etter rapporterting av eGFR, som ble innført i 2004. Deltakerne ble fulgt i perioden 2003-07.

Hyppigheten av nyhenviste pasienter med kronisk nyresykdom (eGFR < 60) steg svarende til en relativ økning på $68 \%$. Det skjedde ingen endringer $\mathrm{i}$ henvisningsmønsteret for pasienter med eGFR $>60$.

\author{
Astma hos mor gir litt hyppigere \\ astma hos barnet enn dersom det \\ er far som er plaget. Det viser en \\ ny metaanalyse.
}

Analysen er basert på 33 pasient-kontrollundersøkelser og tverrsnittsstudier fra perioden 1966-2009 (1). Risikoen for astma hos barn av astmatiske mødre sammenliknet med risikoen for dem som hadde mødre uten astma, var signifikant økt (OR 3,0, $95 \%$ KI 2,6-3,6). Tilsvarende tall når det gjaldt fedrene var 2,4 (95\% KI 2,1-2,8).

Ved en sammenlikning av oddsratioene ga maternell astma en litt større, men signifikant, risiko enn paternell astma $(3,0$ versus $2,4, p=0,037)$. Effekten av hvilken forelder som hadde sykdommen ble svekket og var ikke signifikant ved analyse av studier hvor astma var diagnostisert av lege og i studier med barn over fem år.
- Den ganske lett forhøyede risikoen for selvrapportert astma hos småbarn kan kanskje skyldes den tette kontakten med moren in utero og i de første leveår og dermed felles miljøfaktorer. En annen mulighet er at mødre med astma observerer og gjenkjenner symptomene hos barna i høyere grad. En avklaring av spørsmålet krever en prospektiv studie, sier Ronald Dahl ved lungemedisinsk avdeling ved Århus universitetssykehus (2).

\section{Erlend Hem}

erlend.hem@medisin.uio.no

Tidsskriftet

Litteratur
1. Lim RH, Kobzik L, Dahl M. Risk for asthma in offspring of asthmatic mothers versus fathers: a meta-analysis. PLoS One 2010; 5: e10134. ww.ncbi.nlm.nih.gov/pmc/articles/PMC2853568 (11.5.2010).

2. Høj-Hansen CE. Astmatiske mødre overfører oftere astma til deres børn end astmatiske fedre. Ugeskr Læger 2010; 171: 1429.

\section{$A D / H D$ gir problemer også senere i livet}

Jenter som har fått diagnosen AD/HD, har som unge voksne høy risiko for å få psykiske lidelser. Samme funn er tidligere dokumentert blant gutter, hvor AD/HD er mer utbredt (Am J Psychiatry 2010; 167: 409-17).

I en longitudinell pasient-kontroll-studie ble 6-18 år gamle jenter med AD/HD ( $n=96$ ) og 91 kontrolldeltakere fulgt opp i 11 år. Deltakerne ble vurdert med strukturelle kliniske intervjuer ved 22 års alder (gjennomsnitt). Livstids- og ettårsrisiko for alle kategorier av psykososiale lidelser var signifikant forøket for jentene med AD/HD sammenliknet med kontrollgruppen. $62 \%$ av jentene med $A D / H D$ hadde fortsatt invalidiserende $A D / H D$-symptomer.

\title{
Genetisk disposisjon for lungekreft hos aldrirøykere
}

\section{Nedregulering av genet GPC5 er assosiert med lungekreftutvikling hos dem som aldri har røykt.}

Trolig bør lungekreft hos røykere og lungekreft hos aldrirøykere anses som to ulike entiteter. En ny studie tyder på at nedregulering av genet $G P C 5$ er involvert i tobakksuavhengig lungekreft (1). Basert på genetisk screening av 754 aldrirøykere (377 pasient-kontroll-par) plukket forskerne ut 44 genetiske normalvarianter, såkalte polymorfismer, for videre undersøkelser. Analyser av nye og uavhengige pasientgrupper bekreftet at polymorfismer som nedregulerer GPC5-uttrykk er hyppigere blant individer med lungekreft og viste også at at GPC5 er lavere uttrykt i svulstvev enn normalvev.

- Det er kjent at lungekreft hos dem som aldri har røykt har en annen klinisk og molekylær profil enn lungekreft hos røykere, sier overlege Åslaug Helland ved Oslo universitetssykehus, Radiumhospitalet. - I tidligere publiserte helgenomassosiasjonsstudier på lungekreft har man identifisert gener involvert i nikotinbetabolismen. Det er naturlig at andre gener påvirker risikoen for utvikling av lungekreft hos aldrirøykere, og det er prisverdig at dette blir undersøkt, sier hun.

- Denne studien viser at varianter av genet GPC5 sannsynligvis er involvert i risikoen for utvikling av lungekreft hos aldrirøykere. Proteinet GPC5 er et proteoglykan og interagerer blant annet med mange ulike vekstfaktorer og kjemokiner. Det ser ut til å ha ulike funksjoner i ulike vev. Genet er tidligere funnet både amplifisert og tapt i ulike krefttyper.

Analyser som inkluderer informasjon om både gener og genuttrykk, er viktige bidrag til økt forståelse av prosessene som er involvert i kreftutvikling. Dette er kunnskap som kan avdekke nye angrepspunkter for profylakse og terapi, sier Helland.

\section{Jon Amund Kyte}

jon.amund.kyte@rr-research.no

Tidsskriftet

\section{Litteratur}

1. Li Y, Sheu CC, Ye Y, et al. Genetic variants and risk of lung cancer in never smokers: a genome-wide association study. Lancet Oncol 2010; 11: 321-30. 